\title{
INFORMATION NEEDS OF INDONESIAN INFERTILE PATIENTS ABOUT CROSS-BORDER REPRODUCTIVE CARE
}

\author{
Rumyeni \\ Universitas Riau \\ rumyeni@lecturer.unri.ac.id \\ Susanne Dida \\ Purwanti Hadisiwi \\ Yanti Setianti \\ Universitas Padjadjaran \\ susanne.dida@unpad.ac.id \\ purwanti@unpad.ac.id \\ yanti.setianti@unpad.ac.id
}

\begin{abstract}
Infertile patients need to prepare variety of information before decided to perform reproductive care procedures in foreign country. Sufficient information will help the reproductive care run smoothly. The purpose of this study is to determine the source of information, the necessary information, and the barriers to fulfill the necessary information of Indonesian infertile patients undergoing IVF programs in Malaysia. This study used qualitative method by conducting indepth interviews with 11 infertile patients who had IVF experience in Malaysia. Results showed that infertile patients obtained information about the IVF program in Malaysia through four sources of information, namely: 1) personal sources such as friends and family; 2) online media which includes the google search engine, blogs and youtube; 3) medical professionals, whether doctors, nurses or other medical personnel; and 4) seminars held by hospital management. Patients information needs include specific information about IVF, medical system information, cost information, IVF legal information, and easiness information in the destination country. Language was found as an obstacle in fulfilled information needs. In conclusion, this study provides new knowledge about various sources of information used by infertile patients in fulfil their information needs about cross-border reproductive care procedures, with language as one of the obstacles.
\end{abstract}

Keywords: Health Communication; Patient Information Needs; Cross-border Reproductive Care; Infertility

\section{INTRODUCTION}

Today more patients are travel to other countries for medical treatment. Some of the reasons for this include long waiting lists, high cost of care in the home country, or seek for higher level medical treatment (Ngamvichaikit \& Beise-Zee, 2014). Among the types of medical treatment that are in great demand by patients abroad is reproductive care. The activity of traveling abroad to get reproductive care is known as cross border reproductive care (CBRC). CBRC is the practice of traveling to other countries for fertility treatments such as 
IVF, intra-cytoplasmic sperm injection, sperm donation, egg donation, embryo donation, commercial surrogation, Pre-implantation Genetic Diagnosis (PGD), gender selection, and preservation of fertility (Salama, 2015). In Indonesia, many infertile patients choose Malaysia for reproductive care. The Malaysia Healthcare Travel Council (MHTC) noted that at least 4,000 patients underwent IVF in Malaysia during 2019 (Handayani, 2020).

Infertile patients who want to carry out reproductive care in different country need complex and detailed information, both medical and non-medical information. Seeking information is the second step taken by couples after they admit to having a problem (Porter \& Bhattacharya, 2008). Understanding of this information affects the readiness of the patient in making decisions regarding the treatment procedure to carry out. Adequate knowledge is an important component in decision making (Dane et al., 2018). High quality information which delivered in a structured manner, can have a positive impact on patients' awareness of their condition and can reduce anxiety (Ahmadizadeh et al., 2017), building trust, encourage medical care adherence and reduce the risk of errors and harm (Braaf et al., 2018). Dissatisfaction with the information provided by fertility clinics is one of the reasons why couples seek information elsewhere, for example from family members, friends, books, and the media (Mounce, 2013).

Providing information to infertile patients is not easy, this is due to their condition, the desire to have children, and the complexity of treatment options (Mounce, 2013). Describing disease is one of the most important yet most challenging communication tasks in medical care practice. A number of studies show that patients feel dissatisfied because a lack of explanation about their condition (Ishikawa et al., 2017). Most patients wanted information as much as possible, however doctors are often unaware of it.

One of the problems of infertile patients in Indonesia is a very limited access to information related to fertility treatments. Researchers tried to trace information about crosscountry reproductive care, especially IVF, information related to treatment procedures, processes, alternative treatments, non-medical information such as accommodation issues, interactions and communication with medical professionals and local residents in the destination country, treatment administration and others are still very few available in various media and other reference sources. Of course, this is an obstacle for infertile patients, the lack of this information can make patients less confident in determining the treatment decisions they should take or just surrendering the alternative treatments offered by doctors. This phenomenon is inversely proportional to medical tourists who came from developed countries. Research that has been conducted in Thailand on medical tourists from western countries actually shows that these patients are considered to have very good information regarding medical and non-medical problems before they decided to seek medical treatment in other countries, so that sometimes these patients were assessed. to test the ability and knowledge of doctors in Thailand about the medical problems they face (Ngamvichaikit \& Beise-Zee, 2014).

The topic of health communication is getting more attention and attracting scientists. One of the themes of health communication that is often found in scientific publications is health information. Studies on information needs in medical field have been conducted before (Braaf et al., 2018; Gleeson et al., 2013; Wardani et al., 2018; Wen et al., 2014), but as far as we know, no one has examined it regarding to the information needs of infertile patients undergoing cross-country reproductive care. Knowledge about the need of infertile patient will contribute both for patients who have desire to take infertility treatment to a foreign country or to destination hospital. The purpose of this study is to determine the sources of information, information needs and constraints faced by Indonesian infertile patients in fulfilling the information needs of seeking cross-border reproductive care through the IVF program in Malaysia. 


\section{LITERATURE REVIEW}

The field of communication has a very broad scope. One of them is health communication. Health communication is a field of science that studies how to use communication strategies to expand health information that can influence individuals and communities so that they can make the right decisions related to health management (Liliweri, 2018). Health communication is a partnership process between participants based on a twoway dialogue in which there is an interactive atmosphere, exchange of ideas, and agreement on a unity of ideas about health. It is also a technique for the sender and receiver of information to obtain information about balanced health for updating mutual understanding (Liliweri, 2018). Sufficient information is required from each party so that a common understanding can be achieved.

Everyone basically is a searcher and user of information. In the health sector, the information needed, sought and used by someone is accordance with the type of need (Yusup \& Komariah, 2018), especially if that person is a patient suffering from a disease or facing certain medical problems. In fulfilling the health information needs, patients can get this information from various sources, they can access it through mass media, social media, books, ask medical practitioners, or other patients who have the same health problems. Of course, each source of information has different credibility and accuracy.

The concept of information needs does not have a single definition, but depends on the perspective of its application. In order to understand the term information needs, it is important to know how it fits into the general context of human needs research. Information needs are difficult to define and measure because they involve cognitive processes with different levels of awareness (Tawaf \& Alimin, 2012). In-depth understanding of information needs is essential to answer some of the following big questions: 1) How are information needs created; 2) What motivates people to seek information; 3) Why do people sometimes avoid information; 4) How people express their information needs; 5) How relevance is considered; 6) How should information organized and managed properly to respond and anticipate community needs; and 7) How we should organize and plan the expression of information needs (Naumer \& Fisher, 2017). According to Krikelas, the need for information is a person acknowledgment of the uncertainty that drives him to seek information (Tawaf \& Alimin, 2012).

An infertile patient tends to face complex problems related to fertility, because the causes of infertility can vary for each partner. So, when someone was sentenced to be infertile, various questions would appear that needed to be answers in order to overcome the problems that experienced. These questions will encourage patient to seek as much information as possible. Sufficient information will allow the patient to reduce anxiety and be able to decide what the next steps should be.

In order to understand the information needs of patients and how infertile patient information seeking behavior in fertility treatment across countries, researchers used the information seeking behavior model by Wilson (1999). Information seeking behavior is an effort to find information with a specific purpose as a result of the need to fulfill certain goals (Rohmiyati, 2018). In an effort to find information, a person can obtain it manually, such as from newspapers or libraries, or through computer-based systems, such as the world wide web or the internet (Wilson, 1999). Wilson's model explains that information seeking behavior comes from the need for information by users, and a response to these needs demands information systems such as libraries or databases, and other sources of information such as text books, handouts, lecturers and others. With the rapid development of the internet as it is today, more users access online media to fulfill their information needs.

When an infertile patient decides to do fertility treatment abroad, she needs a lot of information, because she faces a lot of uncertainty. Performing fertility treatment in a foreign 
country will face various possibilities such as differences in linguistic and cultural backgrounds, hospital management or fertility clinics, and it is not uncommon for patients to find examinations with different results compared to examinations carried out in the country of origin so that alternative treatment options will also be different.

\section{METHOD}

This research uses descriptive qualitative method. The aim is to understand the phenomena that occur or are experienced by research subjects (Wardani et al., 2018). The research was conducted in Pekanbaru, the capital city of Riau province. This location was chosen because geographically Pekanbaru is located close to Malaysia, the destination of majority Indonesians patient for reproductive treatment. The research was conducted for 9 months, from November 2019 to July 2020.

11 infertile women who had experience doing IVF programs in three hospitals and fertility clinics in Malaysia were chosen as informants. Informants were selected using a purposive method. Several criteria for informants have been determined: 1) The patient has an IVF program in a hospital or fertility clinic in Malaysia at least once, 2) The patient has a legal marital status, and 3) The patient has performed the IVF procedure according to legal regulations in Indonesia.

Researchers conducted in-depth and semi-structured interviews with all informants. A total of eight informants were interviewed face-to-face, and three others were interviewed by telephone due to the pandemic situation that made face-to-face interviews impossible. The locations for the interviews were conducted at the informant's residence, office, and also at the cafe, depending on the agreement with the informant. Each interview lasted between 30 minutes and 2 hours. All interviews were recorded and then transcribed word for word. In addition to interviews, researchers also conducted participant observations by following patients undergoing an embryo transfer procedure at a fertility clinic in Kuala Lumpur. The researcher acts as the patient's family and pays attention to how the patient digs up information when consulting doctors, nurses and other medical practitioners.

The data analysis technique uses Miles and Huberman's analysis which consists of three lines, namely data reduction, data presentation, and conclusion or verification. Researchers used a technique to check the validity of participation extension data by following the IVF process carried out by one of the infertile patients at a fertility clinic in Kuala Lumpur. In addition, the researcher also conducted triangulation by comparing the data obtained through interviews with observations at the fertility clinic, and comparing the results of the informants 'interviews with statements from the informants' families.

\section{RESULTS AND DISCUSSION}

The activity of traveling abroad to get fertility treatment, especially the IVF program, is usually the last alternative taken by infertile patients from Indonesia after the patient has previously made various medical and non-medical treatment efforts in Indonesia. In the decision-making process, patients need a variety of information that can convince them to carry out the procedure. This information includes the causes of their infertility, what alternatives are available to overcome the problem, which hospital to go to, which doctor they should choose, how much money must be prepared, how the process and treatment procedure will be carried out, and so on. Patients' information needs may different, depending on their interests.

At the beginning of the IVF process, some patients claim they have no knowledge of IVF and feel confused. As said by YR, an infertile patient who has undergone four IVF programs at Mahkota Medical Center, Melaka. She said: 
"At first I was a bit lacking in information. In 2012 there was not much information about IVF, so it was a little difficult for me to find the information. That's why I was confused when I met the doctor, I didn't know what to ask" (Interview with YR, 28 November 2019).

Insufficient information for patients, makes patients feel confused and do not know what to ask the doctor. The situation becomes more complicated if the doctor is less communicative. But usually after meeting with the doctor the patient will get an overview of the IVF program. Furthermore, YR said:

"So when I got a picture of IVF then I looked for information from the online media. I wrote questions that were not answered through online media, starting from how the process, how long the program, many kinds of things I asked. I prepared a paper to ask for the details. So before deciding to do the program, we really need to know sufficient information" (Interview with YR, 28 November 2019).

This statement is supported by NV, an infertile patient who has had two IVF programs at the KL Fertility Center. She said:

"Even though I already have information from Google, until the hospital I still ask about IVF. At first I didn't know about IVF, I only knew bayi tabung. This is one of the different terms in Indonesia and Malaysia. They don't know the term bayi tabung, which means IVF" (Interview with NV, 23 November 2019).

Couples seeking fertility treatment are generally thirsty for information about available treatment options and how to help themselves to achieve pregnancy (Porter \& Bhattacharya, 2008). In an effort to overcome the infertility, patients who are usually laymen about medical problems, actively seek information as much as possible from various available sources. The use of information resources is very important because meeting information needs can only be obtained by searching for the right information. In addition, adequate information will eliminate confusion and anxiety faced by patients. Furthermore, adequate information will also make patients feel well prepared for all the risks regarding to treatment outcomes considering that IVF has varying success rates, the older patients the greater the risk of failure.

\section{Source of Information}

Information is one of the main strength for patients who are going to carry out the IVF procedure, especially when the procedure is carried out abroad. Patients can use various sources of information to obtain the information they need. Information sourced can be directly from people who had the same experience, newspapers, books, or the internet (Wilson, 1999).

Patients cannot rely on just one source to find information, because each source usually has weaknesses. To obtain complete information, patients must seek comprehensive information from various sources, so that patients will have adequate information and feel completely confident in carrying out the IVF procedure.

\section{Personal Source}

The majority of patients stated that they received information about the IVF program in Malaysia from friends, neighbors and relatives who had previously undertaken the program. Some patients also seek information directly from other patients. When people around infertile 
patients know the problems faced by patients, most of them are given information and recommendations to try alternative IVF programs to Malaysia. As stated by EK, she said: "I only get information from my friends. I never looked for IVF information from the internet or other media. At the hospital I also did not seek information anymore. I went straight to the doctor, examined, then I was stated that I had to undergo IVF" (Interview with EK, 6 June 2020).

DW, a patient who works as a teacher, admitted that he immediately decided to do IVF in Malaysia because he had received information from his family who had previously tried the IVF program in Malaysia. She said:

"I decided directly undergo the IVF program in Malacca and I didn't think about going anywhere else because many of my family had been there. My friend also said that you shouldn't go to Jakarta because it would be a waste of time" (Interview with DW, 20 April 2020).

There are also patients who get information from their neighbors who work as a doctors, and have done IVF at Mahkota Medical Center, Melaka. She said:

"I chose IVF to Melaka because I got information from my neighbor who is a doctor, he said it was better to consult with the doctor there. We can ask all kinds of questions. So I chose to go to Melaka because it's more convenience. Consultation with doctor is more pleasant, we are given explanation until we are satisfied" (Interview with DS, 27 November 2019).

Information that comes directly from people who have had the same experience have a big influence on patients in making decision, especially the choice of doctors and destination hospitals. People who have had it before, usually give recommendations to other patients based on their experiences. On the other hand, patients with minimal experience and information will follow the advice given because of the trust factor to those who have experience in medical treatment.

\section{Online media}

Although most of the patients get information from people who have already had IVF procedures in Malaysia, there are also patients who claim that their main source of information is the internet. Internet became the first reference for obtaining information because they did not have any companion who had experience doing the IVF program in Malaysia. This was stated by YR, she said:

"So the internet was my first reference point to look for information because at that time I didn't know anyone who had done the IVF program that I could ask. Actually, it's better if you can ask directly to patient who had undergo IVF programme because they already have experience. One of the sources of information that I read is from blogs. I read the experiences of a patient who had IVF in Malaysia, that's one things that helped me. So the blog is a forum for sharing information, there are questions and answers about the IVF experience" (Interview with YR, 28 November 2019).

The same thing was stated by $\mathrm{YN}$, an infertile patient who works as a doctor at the Riau Provincial Hospital. He did the IVF program at the Genesis Penang fertility clinic. She says: 
"In looking for information about IVF, I used internet like Google search engine and Youtube. I never ask other people, except those who have done the IVF program" (Interview with YN, 2 December 2019).

For patients whose main source of information is friends or family, the internet is only used as a complementary source of information. The internet also used by patients to find additional information. However, the behavior of infertile patients who frequently seek for additional source of information only make them more confused and increases their anxiety (Mounce, 2013).

In this study, we found that some patients didn't use the internet to find information at all, they only relied on information from their friends or from medical practitioners they had met. As stated by DW. She said:

"I received information about IVF for the first time from my family. I never looked for information on the internet" (Interview with DW, 20 April 2020)

Another patient EK said the same thing. She said:

"I only get information about IVF from my friends. I have never accessed the internet to find information" (Interview with EK, 6 June 2020).

Although the internet is not the main source of information for most patients, some even does not access information at all from the internet, but the internet is still used as a reference source which remains an option due to the ease of access factor. The google search engine is widely used by patients. Furthermore, patients also access blogs to get information from other patients who had similar experiences. Usually blogs are used as a source of information by patients who does not have any companion with IVF experience. The advantages of blogs as a site for sharing experiences and exchanging messages, provide benefits for patients to get information from other patients who have previously done IVF programs in Malaysia.

In addition, there are also patients who access IVF information through social media youtube. Through youtube, patients can get a clearer picture because of support the video. Various contents related to IVF are available on youtube, such as information about patient experiences, IVF procedures, tips for successful pregnancy through IVF, the process of implementing the IVF program, and many more. Patients can easily fulfill their information needs about IVF by watching various video shows on youtube.

\section{Medical Professionals}

Although most patients have obtained initial information about IVF from theircompanion or from online media, complete and detailed information, especially information related to medical problems, is sourced from medical practitioners in hospitals or fertility clinics. Before deciding to do the program, the average patient has an overview of the procedure to be performed. Even when in Indonesia, the average patient already knows their problem, even though they do not yet have certainty about the alternative treatment that must be taken to overcome this problem. As stated by DS, she said:

"First, I got information from my neighbor who is a doctor, he recommended me to try the IVF program at Mahkota. Because the one who provided the information to me was the doctor, so I just believed everything. Then I asked for more detailed information after meeting a doctor in Malaysia" (Interview with DS, 27 November 2019). 
This is supported by the RR statement. She said:

"First I got information about IVF in Malaysia from a friend, then he gave me the phone number of the hospital. After that I called the hospital, the nurse answered the phone. He asked me what I needed, then he told me the schedule, to meet the doctor" (Interview with RR, 25 November 2019).

Another patient with the initials NR said that he got information about IVF directly in Malaysia from the hospital when he took his parents for treatment. According to her, many people who ask other people do not understand about IVF. She said:

"At first I found out about IVF when I brought my mother to Mahkota. I looked for information myself, I saw that there was an IVF program at Mahkota Hospital, that drive me to do the IVF program. If you ask other people, many people don't understand, so I better ask the hospital directly" (Interview with NR, 27 November 2019).

It cannot be denied that medical practitioners are the most trusted source of information for patients. Patient trust is strongly supported by the credibility of medical practitioners and the results of examinations performed on patients. The decision to do the IVF program is usually made after the patient has consulted with a doctor and given an overview of the infertility problems faced by the patients and the solutions offered. Patients also feel confident with doctors in Malaysia because they feel that doctors provide information as is, explain the percentage of success possibility of the program, and there is no impression that doctors give too high expectations just to please patients. In this study, the average time spent by patients in consultation with a doctor was 15 to 30 minutes. With the time allotted, patients can ask anything to the doctor related with the current treatment procedure. The duration of this time is longer than the average consultation time for Indonesian patients, the majority of which is reported to be less than 15 minutes (Mayasari, 2016).

\section{Seminar by Hospital Management}

Patient with the initials DS admitted that he received information about IVF from a seminar he attended at Mahkota Medical Center Hospital, Melaka. At that time he was doing a laparoscopic procedure at the hospital. She and her husband have not thought about doing an IVF program. She said when they were at the hospital, coincidentally a seminar on IVF was being held by the hospital management, so she and her husband decided to attend the seminar while waiting for the next consultation scheduled with her doctor. After attending the seminar, she and her husband discussed about the possibility of IVF and finally they are interested to take IVF Program. She said:

"Incidentally, when I was at Mahkota Hospital for the first time, they held a free IVF seminar. So we participated instead of do nothing at the hotel. So during the seminar, my husband said that might be this is the way from Allah. How many years have we had wasting time. Well, finally decided to try IVF" (Interview with DS, 27 November 2019).

In the process of seeking information about the IVF procedure, almost no infertile patients from Indonesia rely on one source only. Even though their preferences for information sources are different, patients try to find information by utilizing various available sources so that they get as complete as possible information according to their needs. Sources of information are complementary to each other. Uniquely, in this study, none of the infertile patients reported that they received information from other types of media such as books, 
magazines, newspapers, television, and radio. This proves that they have left various conventional sources of information and prefer direct personal information sources as well as from online media that are easier to access.

\section{Patient Information Needs}

The information needs of infertile patients include medical and non-medical information. Information of a medical includes specific information about IVF, how to process it and the procedure, what drugs to take, and others. Meanwhile, non-medical information consists of information about doctors, hospital facilities, costs, transportation, accommodation in the destination country, and others.

\section{Specific Information Needs about IVF}

The basic questions that are usually asked by infertile patients regarding IVF information include what is IVF, how is the IVF procedure, the IVF process, the available alternatives, medications, and the success rate. As told by NV, she said:

"I am looking for information about the procedure, the process, the success rate, and what drugs are given.The one who provided a lot of information at the beginning was the receptionist, the available alternatives, then the nurse directed me to a doctor who was an expert with my infertility problem" (Interview with NV, 23 November 2019).

Patients usually ask specific information about IVF to the doctors or other medical practitioners at the hospital or fertility clinic. Although this information is also media, it is usually only in general and not detailed. So the information from media is only used as an initial description for the patient.

\section{Information Needs about Medical Systems}

Information about the medical system is needed by patients to build trust in doctors and hospitals to be visited. The medical system information mostly patients looking for are the experience and qualifications of doctors, credibility of fertility clinics, facilities and the comfort of fertility clinics. As stated by $\mathrm{YN}$, a patient with the medical profession, before decided to choose a doctor in fertility clinic at Genesis Penang, she has visited several doctors and hospitals in Malaysia. She said:

"First, I'm looking for information about the highest experience hospital, then who is the best doctors at the hospital, yes, of course we choose the best. The last one is information about the hospital facilities" (Interview with YN, 29 November 2019).

Patient decisions in deciding the hospital and doctor cannot be separated from the image of the hospital and doctor. The image is built through media coverage and from the direct experience of patients who have previously performed medical treatment at the hospital.

\section{Information Needs about Cost}

Information about costs usually the first information seek by patients because cost is an important aspect affecting a patient's decision on IVF program. Many infertile couples gave up due to financial problem. The costs to perform an IVF procedure are not only related to medical 
procedures, but also transportation from origin country to destination country, local transportation during the IVF process, accommodation while staying in the destination country, food, and other costs.

Each patient spends differences costs, depending on the infertility problem which usually effects the type of medical treatments, the IVF package chosen, transportation and accommodation desired, and other types of expenses that each person can vary. The patient with the initials YR explained how she got information related to costs. She said:

"All the information is clear, the schedule is clear. There is a short process and a long process. The staff explained details of the costs, how much for long process and how much for long proses. In term of cost, each fee must be paid before medical treatment is carried out, and the costs are quite expensive. The cost estimated more or less 100 million rupiah. The payment is not all at once, but depending on the medical treatment being undertaken. I hope that one day I can take IVF program again at a lower cost" (Interview with YR, 28 November 2019).

Another patients, NR shared her experience about the IVF program payment procedure at Mahkota Medical Center Melaka. She said:

"At the time I had received information about the costs, we did not immediately decide for IVF but we started saving. First time we went to the hospital for the IVF program, I only brought 20 million rupiah. It turns out that we pay gradually, not all at once. When embryos transfer treatment, we pay another RM 12 thousand" (Interview with NR, 27 November 2019).

Information related with costs is an important information that is needed by many patients. It is not surprising considering that IVF requires a lot of money and a lot of preparation. In this study, the money spent by patients for the IVF program in Malaysia ranged from 90 million Rupiah to 125 million Rupiah. The cost factor is one of the causes for infertile patients in Indonesia fail to face their infertility problems (Bennett \& Pangestu, 2017). This is because the majority of Indonesia's people has low middle income. Moreover, the Indonesian government does not cover the cost of reproductive care in the government health insurance (BPJS) as has been done in several other countries.

\section{Information Needs about the IVF in Islamic Law}

All informants in this research are Muslims, so that IVF law, especially from the aspect of Islamic law (Shari'ah) is very important for them. As stated by NV, she said:

"Before I decided to undergo IVF program, I looked for information whether

IVF is halal or haram in the Shari'ah. I want to know IVF in Islamic law. I found out that it is permissible under several conditions" (Interview with NV, 23 November 2019).

Another patient with the initials YR also shared her experience about the need for information related to the issue of IVF in terms of Islamic law. She said:

"I am looking for information in Islamic Law about the IVF program. I found that, if it is caused by health problems, it is allowed to undergo IVF program, but it is not allowed to save embryos" (Interview with YR, 28 November 2019).

As citizens of a country where Muslim is the majority population, the spiritual aspect is an inseparable part of the patient's life. Previous research found that one of the reasons Indonesian patients choose to undergo reproductive treatment in Malaysia because they belief 
that procedures carried out in Malaysia are safe and according to Islamic law (Bennett \& Pangestu, 2017).

\section{Information Need for Convenience in Destination Countries}

Other information that is also important for Indonesian infertile patients who wish to undergo an IVF program in Malaysia is information about accommodation, transportation and restaurant available around the hospital. Before they go to Malaysia, some of this information where asked to other people who already have experience going to Malaysia, and also from the internet. EC, an infertile patient who has frequently traveled to Malaysia before, received information from his family about the convenience of Malacca. She said:

"There are many hotels around the hospital with affordable prices. If we want to eat, just walk, it's available near the hospital. The hospital also provides shuttles from the airport. Almost all hospitals provide transportation to the airport" (Interview with EC, 28 November 2019).

Convenience in the destination country is a supporting factor that cannot be ignored, given that the IVF process usually requires a relatively long time and repeated visits. Transportation and accommodation are considered by patients because they require a large amount of money beyond the cost of IVF.

\section{Fulfilling Information Needs Barrier}

Although in general patients feel that their information needs are fulfilled, some patients admit that they face obstacles in fulfilling their information needs, including language barriers. The majority of medical practitioners in hospitals and fertility clinics in Malaysia use English mixed with Malay in everyday conversation, and some even speak fully English. Some patients claim to have limitations in understanding English so that they find it difficult to ask questions due to these obstacles. As experienced by NV, she said:

"I feel there is a language barrier. Doctors and nurses speak mostly English. I find it a bit difficult to communicate and there are difficulties with Chinese nurses, but with India nurses, it can still be understood" (Interview with NV, 23 November 2019).

These obstacles caused some information from medical practitioners could not understand properly. Previous research on the information needs of Chinese cancer patients in America has shown the same. Language barriers and poor communication with health care providers are generally reported to interfere the access to health services (Wen et al., 2014). Information by medical practitioners using language that is not understood makes patients feel confused and dissatisfied (Braaf et al., 2018). Patients who do not speak English are less able to understand, communicate, and exchange information and make treatment decisions (Mounce, 2013). However, usually patients will ask family members for help in overcoming this problem, although this also has drawbacks, one of which is the accuracy of the translation.

\section{CONCLUSION}

The results of this study provide valuable knowledge about the sources and information needs of infertile patients undergoing cross-border reproductive care. Many patients feel that doing medical treatment in a different country is a new and challenging experience, so they must prepare themselves as well as possible, one of which is by seeking information through various sources. Many patients admit that they do not have sufficient information when 
deciding to undergo an IVF procedure. Along with the treatment process, they obtain the information they need from a variety of sources. In general, patients' information needs can be meet during reproductive treatment, although some patients experience language barriers.

Based on the research results, it is suggested infertile patients who intend to carry out cross-border reproductive care to increase their reproductive health literacy skills so that they have sufficient information stock before deciding to run the program. Currently, information from online media is abundant and easily accessible, relying on personal information from friend and relatives certainly cannot fulfill patient information needs because everyone's experience can be different. The results of this study pose a challenge for healthcare providers in Malaysia to overcome language barriers to make communication between medical practitioners and patients from Indonesia more effective and efficient. The success of the treatment is influenced by the patient's understanding of the health information provided.

The limitation of this study is only looking at the information needs from the patient's point of view, the next research will be more complete if the researcher also looks at the experiences of the patient's spouse or family because usually patients who are doing the IVF program are also accompanied by their spouse or family. It is not uncommon for doctors or nurses to actively involve the patient's partner and family to communicate and discuss the patient's health problems. Future research also needs to look at patient information satisfaction quantitatively in order to measure the gap between the expected information and the reality of the information obtained.

\section{REFERENCES}

Ahmadizadeh, S., Bozorgi, A. S., \& Kashani, L. (2017). The role of information therapy in reducing anxiety in patients undergoing in vitro fertilisation treatment. Health Information and Libraries Journal, 34(1), 86-91. https://doi.org/10.1111/hir.12169

Bennett, L., \& Pangestu, M. (2017). Regional reproductive quests: Cross-border reproductive travel among infertile Indonesian couples. Asia Pacific Viewpoint, 58(2), 162-174. https://doi.org/10.1111/apv.12160

Braaf, S., Ameratunga, S., Nunn, A., Christie, N., Teague, W., Judson, R., \& Gabbe, B. J. (2018). Patient-identified information and communication needs in the context of major trauma. BMC Health Services Research, 18(1), 1-13. https://doi.org/10.1186/s12913018-2971-7

Dane, A. C., Peterson, M., \& Miller, Y. D. (2018). Talking Points: Women's Information Needs for Informed Decision-Making About Noninvasive Prenatal Testing for Down Syndrome. Journal of Genetic Counseling, 27(5), 1258-1264. https://doi.org/10.1007/s10897-018-0250-8

Gleeson, M., Meiser, B., Barlow-Stewart, K., Trainer, A. H., Tucker, K., Watts, K. J., Friedlander, M., \& Kasparian, N. (2013). Communication and information needs of women diagnosed with ovarian cancer regarding treatment-focused genetic testing. Oncology Nursing Forum, 40(3), 275-283. https://doi.org/10.1188/13.ONF.40-03AP 
Handayani, I. (2020). 4000 Pasien Indonesia Jalani Program Bayi Tabung di Malaysia. https://investor.id/lifestyle/4000-pasien-indonesia-jalani-program-bayi-tabung-dimalaysia

Ishikawa, H., Son, D., Eto, M., Kitamura, K., \& Kiuchi, T. (2017). The information-giving skills of resident physicians: relationships with confidence and simulated patient satisfaction. BMC Medical Education, 17(1), 1-6. https://doi.org/10.1186/s12909-0170875-6

Liliweri, A. (2018). Dasar-Dasar Komunikasi Kesehatan. Pustaka Pelajar.

Mayasari, F. (2016). Analisis Hubungan Waktu Pelayanan dan Faktor Total Quality Service Terhadap Kepuasan Pasien di Poliklinik Kebidanan dan Kandungan RSIA Anugerah Medical Centre Kota Metro Tahun 2015. Jurnal ARSI, 2(3), 214-230.

Miles, M. B., \& Huberman, A. M. (1992). Analisis Data Kualitatif: Buku Sumber Tentang Metode-Metode Baru. UI Press.

Mounce, G. (2013). An overview of information giving in fertility clinics. In Human Fertility (Vol. 16, Issue 1, pp. 8-12). https://doi.org/10.3109/14647273.2012.755571

Naumer, C. M., \& Fisher, K. E. (2017). Information Needs. Encyclopedia of Library and Information Science, 2452-2458. https://doi.org/10.1081/E-ELIS3-120043243

Ngamvichaikit, A., \& Beise-Zee, R. (2014). Communication needs of medical tourists: An exploratory study in Thailand. In International Journal of Pharmaceutical and Healthcare Marketing (Vol. 8, Issue 1). https://doi.org/10.1108/IJPHM-10-2012-0010

Porter, M., \& Bhattacharya, S. (2008). Helping themselves to get pregnant: A qualitative longitudinal study on the information-seeking behaviour of infertile couples. Human Reproduction, 23(3), 567-572. https://doi.org/10.1093/humrep/dem398

Rohmiyati, Y. (2018). Model Perilaku Pencarian Informasi Generasi Milenial. ANUVA, 2(4), 387-392.

Salama, M. (2015). Cross Border Reproductive Care (CBRC): A Global Perspective. Obstetrics \& Gynecology International Journal, 1(2), 8-10. https://doi.org/10.15406/ogij.2014.01.00008

Tawaf, \& Alimin, K. (2012). Kebutuhan Informasi: Sebuah Pendekatan Kepustakaan. Kutubkhanah, $\quad 15(1), \quad 50-59 . \quad$ http://ejournal.uinsuska.ac.id/index.php/Kutubkhanah/article/view/249

Wardani, T. R. K., Suwignyo, H., \& Ernaningsih, D. N. (2018). Kebutuhan Informasi dan Upaya Pemenuhan Kebutuhan Informasi pada Komunitas Akar Tuli. BIBLIOTIKA: Jurnal Kajian Perpustakaan Dan Informasi, 2(2), 105-112. https://doi.org/10.17977/um008v2i22018p105

Wen, K.-Y., Hu, A., Ma, G. X., Fang, C. Y., \& Daly, M. B. (2014). Information and Communication Needs of Chinese American Breast Cancer Patient: Persfectives on Survivorship Care Planning. Journal Community Support Oncol, 12(2), 349-445. https://doi.org/10.12788/jcso.0095

Wilson, T. D. (1999). Models in Information Behaviour Research. Journal of Documentation, 55(3), 249-270. 
Yusup, P. M., \& Komariah, N. (2018). Penggunaan Sumber-Sumber Informasi Kesehatan di Kalangan Penduduk Miskin Pedesaan. In Komunikasi Kesehatan: Pemikiran dan Penelitian (pp. 164-184). Remaja Rosdakarya.

\section{About the authors}

Rumyeni, senior lecturer in department of Communication Science, Faculty of Social and Political Science, Universitas Riau, Pekanbaru and Doctoral student in Faculty of Communication Science, Universitas Padjadjaran, Bandung.

Susanne Dida, Associate Professor in Faculty of Communication Science, Universitas Padjadjaran, Bandung.

Purwanti Hadisiwi, Associate Professor in Faculty of Communication Science, Universitas Padjadjaran, Bandung.

Yanti Setianti, Associate Professor in Faculty of Communication Science, Universitas Padjadjaran, Bandung. 